\title{
PENGARUH PENGGUNAAN STRATEGI SELF-MANAGEMENT DALAM KONSELING KELOMPOK TERHADAP INTENSITAS MINAT BELAJAR SISWA KELAS X SMK AL-ISLAH SURABAYA
}

\author{
Indra Ovalia \\ Program Studi Bimbingan Konseling Fakultas Keguruan dan Ilmu Pendidikan \\ Universitas PGRI Adi Buana Surabaya \\ Email: indraovalia2011@yahoo.com

\section{Hartono} \\ Program Studi Bimbingan Konseling Fakultas Keguruan dan Ilmu Pendidikan \\ Universitas PGRI Adi Buana Surabaya \\ Email: hartono140@yahoo.com
}

\begin{abstract}
Abstrak
Minat belajar siswa adalah suatu ketertarikan seorang siswa dalam aktivitas belajar yang didasari oleh empat atribut, kognisi (memperhatikan), afeksi (perasaan senang), konasi (memiliki kehendak), dan tindakan. Tujuan penelitian ini adalah untuk menguji signifikan pengaruh penggunaan strategi selfmanagement dalam konseling kelompok terhadap intensitas minat belajar siswa kelas X SMK Al-Islah Surabaya. Metode penelitian yang digunakan adalah penelitian praeksperimental dengan rancangan One Group Preetest Posttest Design, pada populasi 70 orang siswa kelas X SMK Al-Islah Surabaya. Dari populasi tersebut diambil sampel sebanyak 6 orang siswa dengan menggunakan teknik purposive sampling. Metode pengumpulan data menggunakan skala pengukuran yang telah dilakukan uji validitas butir dan uji reliabilitas alpha cronbach.Hasil uji validitas butir skala pengukuran minat belajar siswa antara 0.051-0.282, sedangkan hasil uji reliabilitas alpha cronbach sebesar 0,158. Data penelitian dianalisis mengunakan bantuan SPSS for Windows versi 16.0 dengan teknik analisis Uji Wilcoxon statistika nonparametrik.Hasil penelitian ini disimpulkan terdapat pengaruh positif yang signifikan penggunaan strategi selfmanagement dalam konseling kelompok terhadap intensitas minat belajar siswa kelas X SMK Al-Islah Surabaya.
\end{abstract}

Kata Kunci: Self-Management, Konseling Kelompok, Minat Belajar

\section{PENDAHULUAN}

Minat selama ini hanya

dikenal dengan sebuah keinginan

yang dimiliki oleh seseorang, sehingga antara satu dengan yang lain mempunyai perbedaan dalam keinginannya. Secara bahasa minat berarti kecenderungan hati yang 
tinggi terhadap sesuatu.Minat merupakan sifat yang relatif menetap pada diri seseorang. Terlepas dari anggapan tersebut, minat belajar siswa merupakan bagian penting yang perlu dikaji dalam sebuah lembaga/sekolah, karena tidak ada sekolah tanpa proses pembelajaran, sehingga minat belajar siswa adalah kunci tercapainya visi dan misi sekolah.

Dian Agustina (2009:6), yang melakukan penelitian di SMAN 8 Malang, hasil peneitian menunjukkan bahwa persentase $38.92 \%$ siswa memiliki minat belajar tinggi, persentase $12.5 \%$ siswa memiliki minat belajar sedang, persentase 48.58\% siswa memiliki minat belajar kurang. Lingkungan yang baik dan mendukung akan bisa membentuk minat belajar anak namun sebaliknya, lingkungan yang kurang mendukung dan kurang baik akan membentuk minat belajar anak yang malas dan menurun.

Malas adalah salah satu masalah yang sangat meresahkan di dunia pendidikan saat ini.Malas memang bukan hal baru tapi juga hal lama.Bukan hal baru karena sudah lama masalah ini terjadi dan bukan hal yang lama karena masalah ini belum teratasi.Bila anak didik malas, maka yakinlah bahwa ada yang salah dengan hal itu.Hanya satu hal yang bisa menyebabkan kemalasan siswa, yaitu kurangnya minat.Tidak banyak pendidik tahu ini, apalagi memahaminya.Seorang anak malas belajar disebabkan oleh kehilangan minat.Seorang anak kehilangan minat saat mereka takut dengan kegagalan, jadi hal ini yang membuat anak urung melakukan sesuatu dengan alasan ingin menghindari kegagalan.

Perhatian ini dapat terjadi dengan sendirinya maupun karena pengaruh dari luar, terutama dari orang tua maupun guru, (http://www.seputar-

indonesia.com/edisicetak/contenct/vi ew/390664/50) di akses tanggal 20 April 2010 pukul 18.17 WIB. Berdasarkan analisis deskriptif persentase menunjukkan bahwa faktor intern termasuk kategori baik $(69,6 \%)$, dan faktor ekstern termasuk kategori cukup baik $(62,2 \%)$ sedangkan minat belajar siswa termasuk kategori tinggi (76,5\%). 
Besarnya pengaruh faktor intern adalah $(0,571)$ atau $32,6 \%$ sedangkan untuk faktor eksternal adalah $(0,484)$ atau 23,42\%. Dengan demikian menunjukkan bahwa faktor intern memberikan kontribusi yang lebih besar terhadap minat belajar siswa dibandingkan dengan faktor ekstern.

Kemalasan pada siswa akan dapat mengakibatkan minat belajar siswa berkurang. Seorang siswa tidak mungkin dapat menguasai semua mata pelajaran. Mungkin ada siswa yang unggul di satu pelajaran saja. Kemudian orang tua justru memberikan anak les di pelajaran yang lemah tadi. Pelajaran yang kurang didorong terus dan dipaksakan sehingga anak menjadi tertekan. Akhirnya, siswa menjadi stres, keunggulannya hilang dan minat belajarnya menurun. Siswa yang malas belajar akan santai saja dalam menghadapi Ulangan Harian, Ulangan Tengah Semester, Akhir Semester, Try Out atau mungkin dalam menghadapi Ujian Nasional (UNAS). Pada saat itu, siswa yang tidak belajar akan mengambil jalan pintas dengan menyontek, sehingga banyak siswa yang mendapatkan nilai dibawah SKM pada saat $\mathrm{UH}$, UTS, UAS, nilai Try Out yang jelek dan tidak lulus pada saat UNAS. Hal seperti inilah yang mengakibatkan penurunan prestasi siswa yang juga merugikan orang tua, sekolah, dan kedepannya nanti Indonesia akan selalu kalah dalam bersaing di bidang ilmu dn teknologi. Menurunnya minat belajar siswa tersebut tentunya bisa diatasi, agar tujuan pendidikan dapat tercapai.

Dampak dari menurunnya minat belajar siswa adalah semakin banyak siswa yang menyontek ketika ujian, hal ini dilakukan karena mereka kurang percaya diri yang disebabkan oleh kurang membaca sehingga pengetahuannya minim. Selain itu, tugas yang terkumpul atau dikumpulkan oleh siswa semakin tidak bermutu dikarenakan motivasi belajar siswa menurun sehingga mempengaruhi pola belajar siswa yang selalu meniru atau mencontek pekerjaan teman lainnya apabila guru tidak jeli dalam mengoreksi tugastugasnya hal ini akan terus berlanjut.

Menurunnya minat belajar siswa mempengaruhi prestasi siswa dalam belajar yang lebih menakutkan 
apabila minat ini mempengaruhi siswa dalam menghadapi ujian, bisa saja siswa tidak lulus ujian. Penurunan minat belajar juga akan mempengaruhi kedepannya, apakah siswa mampu membedakan yang benar dan yang salah, yang baik dan yang buruk.

\section{METODE}

Penelitian ini merupakan penelitian praeksperimental dengan rancangan One Group PretestPosttest Design, yang bertujuan untuk mengetahui taraf signifikansi pengaruh penggunaan strategi selfmanagement dalam konseling kelompok terhadap minat belajar siswa. Teknik pengambilan subjek penelitian dilakukan dengan teknik purposive sampling, sedangkan pengumpulan data penelitian dilakukan dengan cara mengerjakan lembar skala pengukuran yang telah dilakukan uji validitas butir dan uji reliabilitas alpha cronbach. Koefisien hasil uji validitas butir skala pengukuran minat belajar siswa antara 0.051-0.282, sedangkan hasil uji reliabilitas alpha cronbach sebesar 0,158.Data penelitian dianalisis mengunakan bantuan SPSS for Windows versi 16.0dengan teknik analisis Uji Wilcoxon statistika nonparametrik.

\section{HASIL}

$\begin{array}{rcr}\text { Hasil } & \text { penelitian } & \text { ini } \\ \text { menunjukkan } & \text { bahwa } & \text { terjadi } \\ \text { peningkatan } & \text { rerata (mean) } & \text { score }\end{array}$ variabel minat belajar siswa (posttest) setelah diberikan strategi selfmanagement. Rerata (mean) score variabel minat belajar siswa (pretest) sebelum diberikan strategi selfmanagement adalah 32.1667, sedangkan rerata (mean) score variabel minat belajar siswa (post test) setelah diberikan strategi selfmanagemet menjadi 57.5000 terjadi peningkatan rerata (mean) score variabel minat belajar siswa $78,76 \%$. Berdasarkan hasil analisis data menunjukkan skor minat belajar sesudah perlakuan lebih besar dari pada skor minat belajar sebelum perlakuan, sehingga menjelaskan adanya pengaruh positif penggunaan konseling kelompok selfmanagement untuk mengatasi masalah siswa terutama untuk meningkatkan minat belajar siswa. 


\section{PEMBAHASAN}

Hamalik,

(2001:158)

berpendapat bahwa minat adalah perubahan energi dalam diri (pribadi) seseorang yang ditandai dengan timbulnya perasaan dan reaksi untuk mencapai tujuan. Tanpa adanya tujuan, orang tidak akan berminat untuk berbuat sesuatu. Seseorang siswa melakukan kegiatan belajar selalu mempunyai tujuan mengapa ia melakukan kegiatan belajar tersebut. Oleh karena itu, minat merupakan faktor penting dalam kegiatan belajar. Kedepannya diharapkan minat siswa dapat meningkat dan menjadi lebih berpengaruh dalam prestasi belajar siswa, sehingga orang tuapun ikut bangga dengan hasil yang dicapai oleh anaknya. Apabila minat belajar siswa baik dan berprestasi baik, maka akan membantu meningkatkan mutu pendidikan nasional.

Cormier \& Cormier (1985:519) self-management is a process in which clients direct their own behavior change with any one therapeutic strategy or combination of strategies. Self-management adalah suatu proses dimana klien mengarahkan tingkah lakunya sendiri dengan menggunakan satu strategi atau kombinasi strategi. Menurut Mahoney \& Thoresen mengatakan self-management berkenaan dengan kesadaran dan keterampilan untuk mengatur keadaan sekitarnya yang mempengaruhi tingkah laku individu (fauzan, 1992:35). Nursalim (2005:192) Self-management adalah suatu proses dimana konseli mengarahkan perubahan tingkah laku mereka sendiri, dengan menggunakan satu strategi atau kombinasi strategi. Konseli harus aktif menggerakkan variabel eksternal, eksternal untuk melakukan perubahan yang diinginkan.Walaupun konselor yang mendorong dan melatih prosedur ini, tetapi konseli sendiri yang harus mengontrol pelaksanaan strategi ini.

Dalam menggunakan prosedur Self-management, konseli mengarahkan usaha perubahan dengan mengubah aspek-aspek di lingkungannya atau dengan mengatur konsekuensi. Mappiare (2006:297), self-management menunjuk pada suatu teknik dalam terapi kognitif behavior berlandaskan pada teori 
belajar yang dirancang untuk membantu para klien mengontrol dan mengubah tingkah laku yang lebih efektif, sering dipadukan dengan ganjaran. Prijasaksono \& Sembel (2003) strategi self management berfungsi untuk melepaskan stress, kemarahan, kecemasan, ketakutan, dendam, sakit hati, menghilang rasa sakit hati, menghilang rasa sakit dan penyakit, penyembuhan diri sendiri (self-healding), meningkatkan kreativitas, membantu memecahkan masalah, meningkatkan citra diri dan rasa percaya diri, mencapai prestasi dan meningkatkan kemampuan pembelajaran.

Sukadji, (1983:98) tujuan teknik self-management yaitu agar individu secara teliti dapat menempatkan diri dalam situasisituasi yang menghambat tingkah laku yang mereka hendak hilangkan dan belajar untuk mencegah timbulnya perilaku atau masalah yang tidak dikehendaki. Penelitian yang dilakukan oleh Nanik Asmaul Faridah (2009:88) yang menyimpulkan bahwa ada pengaruh penggunaan startegi self-menagement terhadap disiplin belajar di rumah pada siswa kelas VIII-D SMP Negeri 5 Lamongan.Kemudian penelitian yang dilakukan oleh Yuanita Rosida (2008:14) yang menyimpulkan bahwa ada pengaruh selfmanagement terhadap siswa yang sering tidak mengerjakan pekerjaan rumah (PR) mata pelajaran matematika pada siswa kelas X-1 SMA Negeri 1 Prajekan Kabupaten. Bondowoso. Dari berbagai pendapat diatas dapat disimpulkan bahwa strategi self-management adalah strategi dimana klien mengatur atau mengadakan perubahan perilaku dengan satu atau beberapa kombinasi strategi yang sebagian besar diatur dan diarahkan oleh individu itu sendiri dengan sedikit bantuan dari konselor.

Prayitno (2008:86) konseling kelompok pada dasarnya adalah suatu layanan bimbingan dan konseling yang memungkinkan siswa memperoleh kesempatan untuk membahas dan pengentasan permasalahan yang dialaminya melalui dinamika kelompok. Dinamika kelompok ialah suasana yang hidup, yang berdenyut, bergerak, dan ditandai dengan 
adanya interaksi antar sesama anggota kelompok. Winkel dan Hastuti (2004:198) konseling kelompok adalah suatu proses antar pribadi yang dinamis, yang terpusat pada pemikiran dan perilaku yang disadari, dibina, dalam suatu kelompok kecil mengungkapkan diri kepada sesama anggota dan konselor, dimana komunikasi antar pribadi tersebut dapat dimanfaatkan untuk meningkatkan pemahaman dan penerimaan diri terhadap nilai-nilai kehidupan dan segala tujuan hidup serta untuk belajar perilaku tertentu ke arah yang lebih baik.

Dewa Ketut Sukardi (2002:56) konseling kelompok merupakan konseling yang diselenggarakan dalam kelompok, dengan memanfaatkan dinamika kelompok yang terjdi di dalam kelompok itu. Masalah-masalah yang dibahas merupakan masalah perorangan yang muncul di dalam kelompok itu, yang meliputi berbagai masalah dalam segenap bidang bimbingan (bidang bimbingan pribadi, sosial, belajar dan karir). Latipun (2011:118) konseling kelompok merupakan salah satu 
kegairahan yang besar terhadap sesuatu".

Sardiman (2007:76), minat adalah suatu kondisi yang terjadi apabila seseorang melihat ciri-ciri arti sementara yang dihubungkan dengan keinginan-keinginan atau kebutuhan-kebutuhannya sendiri. Oleh karena itu, apa yang dilihat seseorang sudah tentu akan membangkitkan minatnya sejauh apa yang dilihat itu mempunyai hubungan dengan kepentingan sendiri. Joko Sudarsono, (2003:12) dalam

suaranuraniguru.wordpress.com, minat adalah sesuatu pemusatan perhatian yang tidak disengaja yang lahir dengan penuh kemauannya dan yang tergantung dari bakat dan lingkungannya. Minat juga bisa berarti kesadaran seseorang, bahwa suatu objek seseorang suatu soal atau suatu situasi mengandung sangkut paut dengan dirinya.

Minat belajar adalah kecenderungan dan kegairahan yang tinggi atau keinginan yang besar terhadap sesuatu (Muhibbin Syah, 2008:136). Crow dan Crow bahwa minat belajar atau interest bisa berhubungan dengan daya gerak yang mendorong kita untuk cenderung atau merasa tertarik pada orang, benda, kegiatan, ataupun bisa berupa pengalaman yang efektif yang dirangsang oleh kegiatan itu sendiri (dalam Abd. Rachman Abror, 2004:112).

Safari (2005:111), minat belajar adalah kesenangan dalam melakukan kegiatan dan dapat mengakibatkan gairah seseorang untuk memenuhi kesediaanya dalam belajar. Dalam definisi tersebut dapat disusun indikator minat belajar sebagai berikut: (a) Gairah siswa dalam mengikuti Kegiatan Belajar Mengajar. (b) Inisiatif siswa dalam mengikuti Kegiatan Belajar Mengajar. (c) Respons siswa terhadap materi dan tugas yang diberikan oleh guru. (d) Kesegeraan siswa dalam mengumpulkan tugas dan mengerjakan latihan soal yang diberikan oleh guru. (e) Konsentrasi siswa dalam belajar. (f) Ketelitian siswa dalam mengerjakan tugas dan soal latihan yang diberikan oleh guru. (g) Kemauan siswa untuk belajar. (h) Keuletan siswa dalam mengerjakan tugas dan latihan soal 
yang diberikan oleh guru. (i) Kerja keras dalam mengerjakan tugas dan latihan soal yang diberikan oleh guru. Dengan adanya indikator di atas, dapat diketahui siswa yang berminat, kurang berminat dan tidak berminat dalam mengikuti Kegiatan Belajar Mengajar dalam mata pelajaran. Dari beberapa definisi yang dikemukakan oleh para ahli seperti yang dikutip di atas dapat disimpulkan bahwa, minat adalah kecenderungan seseorang terhadap obyek atau sesuatu kegiatan yang digemari yang disertai dengan perasaan senang, adanya perhatian, dan keaktifan berbuat.

Penelitian pengaruh penggunaan strategi selfmanagement dalam konseling kelompok terhadap kepercayaan diri siswa dengan menggunakan rancangan One Group Pre Test Post Test Design menghasilkan temuan penelitian yaitu terdapat pengaruh positif yang signifikan pengaruh penggunaan strategi selfmanagement dalam konseling kelompok terhadap minat belajar siswa.

\section{PENUTUP}

\section{A. SIMPULAN}

Berdasarkan hasil analisis data dapat disimpulkan bahwa terdapat pengaruh positif yang signifikan penggunaan strategi selfmanagement dalam konseling kelompok terhadap intensitas minat belajar siswa kelas X SMK Al-Islah Surabaya.

\section{B. SARAN}

Dengan dibuktikan bahwa terdapat pengaruh positif yang signifikan pengaruh penggunaan strategi self-managemet dalam konseling kelompok terhadap intensitas minat belajar siswa kelas $\mathrm{X}$ MM I dan X MM II SMK Al-Islah Surabaya, maka dapat diberikan saran sebagai berikut.

1. Untuk meningkatkan minat belajar siswa maka perlu diberikan strategi selfmanagement dalam konseling kelompok agar siswa mampu mengetahui tentang kekurangan dan kelebihan yang dia miliki.

2. Dalam penelitian ini, seorang peneliti harus memahami dengan baik langkah-langkah yang harus 
dilakukan ketika melakukan penelitian.

3. Untuk memudahkan penelitian, di dalam penelitiannya diharapkan peneliti memiliki referensi buku ataupun materi yang memudahkan peneliti dalam menyusun penelitian.

4. Penelitian ini dapat dijadikan rujukan bagi peneliti yang lain dalam melakukan penelitian serupa yang bertujuan untuk mengembangkan strategi yang digunakan untuk membantu siswa. Selain itu dapat dijadikan pedoman penelitian lebih lanjut pada jenjang yang berbeda.

\section{DAFTAR PUSTAKA}

Abror, Abd, Rachman. 2004. Psikologi Pendidikan. Yogyakarta: PT. Tiara Wacana.

Cormier \& Cormier L. S. 1985. Interviewing Strategies for Helpers. Monterey California: Brooks/Cole Co.

Dewa Ketut Sukardi. 2002. Teori Konseling. Yogyakarta: Mitra Matraman.

Dian, Agustina. 2009. Efektifitas penggunaan strategi selfmanagement untuk mengelola minat belajar siswa. Skripsi tidak dipublikasikan. Malang: Universitas Negeri Malang.

Elizabeth B. Hurlock, 2007, Psikologi Perkembangan. Edisi 5. Jakarta: Erlangga.

Joko, Sudarsono. 2003. Pengertian Minat dalam Belajar Siswa. (Online), (http://suaranuraniguru.wordpr ess.com/2011/12/01/minatdalam-belajar-siswa, diakses 17 Januari 2014 pukul 22.40 WIB).

Kavie. 2009. Pengertian Pendidikan (Online), (http://kaviedesign.indonesian-forum.net, diakses pada tanggal 07 Juni 2013 pukul 07.30 WIB).

Latipun. 2011. Psikologi Konseling. Malang: UMM Press.

Mappiere, Andi. 2006. Kamus Istilah Konseling dan Terapi. Jakarta: PT. Raja Grafindo persada.

Muhibbin, Syah. 2008. Pengertian Minat dalam Belajar Siswa. (Online),

(http://suaranuraniguru.wordpr ess.com, diakses 17 Januari 2014 pukul 22.40 WIB).

Nanik Asmaul Faridah. 2009. Pengaruh Penggunaan Strategi Self-Management terhadap Disiplin Belajar di Rumah pada Siswa Kelas VIII-D SMP Negeri 5 Lamongan. Skripsi tidak dipublikasikan. Surabaya: Universitas Negeri Surabaya. 
Nursalim Mochammad. 2005. Strategi Konseling. Surabaya: Unesa University Press.

Prayitno. 2008. Dasar-dasar Bimbingan dan Konseling. Jakarta: Rineka Cipta.

Prijaksono \& Sembel. 2003. Strategi Self-Management. Jakarta: PT Alex Media Computindo Kelompok Gramedia.

Safari. 2005. Pengertian Minat dalam Belajar Siswa. (Online), (http://suaranuraniguru.wordpr ess.com, diakses tanggal 17 Januari 2014 pukul 22.40 WIB).

Sardiman, A.M. 2007. Interaksi dan Motivasi Belajar Mengajar.Jakarta: PT Raja Grafindo Persada.
Slameto. 2010. Belajar dan Faktorfaktor yang Mempengaruhinya. Jakarta: Rineka Cipta.

Sukadji. 1983. Teknik-teknik konseling. (http://superannisaninoz.blogsp ot.com), diakses tanggal 23 Januari 2013 pukul 08.00 WIB).

Winkel dan Hastuti. 2004. Bimbingan dan Konseling. Yogyakarta: Media Abadi.

Yuanita Rosida. 2008. Pengaruh Penggunaan Strategi SelfManagement Terhadap Siswa yang Sering Tidak Mengerjakan Pekerjaan Rumah (PR) Mata Pelajaran Matematika Pada Siswa Kelas X-1 SMA Negeri 1 Prajekan Kabupaten Bondowoso. Skripsi tidak dipublikasikan. Malang: Universitas Negeri Malang. 
